\title{
Representative Bureaucracy and Youth Violence in Juvenile Detention Facilities
}

\author{
Ginger Silvera ${ }^{1}$ \\ ${ }^{1}$ Zayed University, United Arab Emirates \\ Correspondence: Ginger Silvera, Zayed University, United Arab Emirates. E-mail: ginger.silvera@gmail.com
}

Received: June 23, 2015 Accepted: July 14, 2015 Online Published: October 29, 2015

doi:10.5539/par.v4n2p63 URL: http://dx.doi.org/10.5539/par.v4n2p63

\begin{abstract}
This exploratory study uses the representative bureaucracy theory to consider the racial representative role, which suggests that administrators who are minorities are more inclined to represent minority interests. This research examined if racial identity and gender was related to detention officers' perceptions of themselves as advocates for same race and same gender to incarcerated youth and to understand what they perceive are the causes for youth violence. A qualitative study was done on individuals who worked with inmates at the Los Angeles County juvenile detention facilities. The grounded theory approach was used for data analysis by observing common responses among participants. The results of this analysis indicate that detention officers are more likely to pursue the advocate role, especially when officers share the same race and gender to minors.
\end{abstract}

Keywords: representative bureaucracy, criminal justice, race, ethnicity, gender

\section{Introduction}

Detention officers play an important role in working with incarcerated minors because they offer counseling to troubled youth and prevent youth-on-youth violence within juvenile detention centers. Youth violence is noted as a problem that is influenced by gang rivalry and racial tensions (Zhang 2007). The majority of youth that are incarcerated are minorities and increasingly detention officers are also from minority backgrounds (Cohen-Jennings 2010). According to Thompson (1976), the presence of other racial minorities enhances an individual's desire to help their racial group. For instance, Blacks Officers working with Black minors influences beliefs and attitudes that shape the behavior and policy decisions of bureaucrats (Selden 1997). According to the representative bureaucracy theory, bureaucrats that share the same race and ethnicity to the clients they serve would be more likely to pursue an advocate role for their client. Despite the research, minimal attention has focused on using representative bureaucracy and applying it to the juvenile justice field.

Minority youth comprise a large percent of the population in juvenile detention facilities and the number of minority officers who work with juveniles is increasing (Woordes et al. 2001). The purpose of juvenile detention facilities is to provide rehabilitative services to incarcerated minors while keeping the community safe from deviant minors. Minors who enter these facilities may be at a low point in their lives; encountering someone who understands their situation can help improve their behavior. Officers provide short-term care and protection within the juvenile halls and their ability to create a working relationship with minors can be beneficial to both parties (Zhang 2007). Minors need the positive support of officers to assist them in their negative situation by listening and providing respect.

These qualities can create the perception that minors can change their behavior and become better citizens. Detention officers have the ability to motivate young people for change. Often officers are the first positive people that minors encounter because of the negativity in their lives at home and in their environment (Vivian et al 2007). Therefore, officers sharing common characteristics can be very helpful for the purpose of creating good working relationships with minors. This can be an important asset for the purpose of reducing youth violence.

In academic research, Jurik (1985) found that minority officers held more positive orientations toward inmates. As officers feel that they closely identify with inmates based on similar socioeconomic and cultural backgrounds, they will implement advocate roles (Jacobs and Kraft 1978). Minority officers can be more sympathetic to the problems of inmates and be more supportive toward treatment and rehabilitative goals. Incarcerated youth in juvenile facilities are mostly Black and Hispanic (Wordes et al. 2001). Minors who are prone to violence are 
influenced by various factors such as gang affiliation, poverty, drugs, and poor family management practices (Hawkins et al. 2000). Officers are expected to contribute to the process of reform and to reintegrate offenders back into society.

Therefore, this study draws on the literature of representative bureaucracy by taking an exploratory approach on understanding if the racial background and gender of officers identify with an advocate role, which affects their behaviors towards addressing youth violence. This study explores the perspectives of retired detention officers and volunteers that work within the juvenile halls to determine if they perceive officers pursing the advocate role. Since violence is a problem within juvenile halls, the representative bureaucracy theory needs to be explored to determine if this can lead to a possible solution to reducing youth violence.

In the following literature, I provide a brief overview of youth violence. Youth violence is a major problem within juvenile detention facilities. Next, I provide literature about the representative bureaucracy theory and a brief overview of studies that have used the theory. Then, I describe the research methods that was used in this study. A qualitative study was conducted by phone interviews with retired detention services officers and volunteers. And, finally I discuss the policy implications.

\subsection{Youth Violence}

Detained youth are brought into juvenile detention centers based on crimes they committed. The juvenile detention facilities are confined holding areas for youth so they can await their court dates or wait for placement in other facilities. This process can take a few days to a few months. Youth are isolated from their family and friends and are brought into an institutional environment that breeds violence (Holman and Ziedenberg 2006). According to Mendel (2011) youth correctional institutions have high levels of violence, abuse and maltreatment of minors. As of recently, the Los Angeles County Probation department had its U.S. Justice Department federal oversight lifted after six years (Sewell 2015). There were significant amounts of violent acts occurring in juvenile camps in 2006 that caused the U.S. Justice department to probe further into the Los Angeles County Probation department. Other major incidents of youth violence in juvenile detention centers across the country have been consistently reported by the news (Grissom 2012; O'Brien 2015; Balint 2015; Pace 2015; Dance 2012 and Levey 2006)

Some causes of youth violence are overcrowding of minors in facilities, understaffing, gang affiliation and racial tensions (Zhang 2007). In addition, the stress of minors awaiting their court trials can also lead to youth violence (Dance 2012). One of the goals of the California juvenile justice system is to ensure public safety and provide treatment and rehabilitation to youth (LAO 1995). Some of the responsibilities for detention services officers is to supervise minors and maintain security as well as provide counseling (LA County Probation 2013). According to Van Voorhis and Salisbury (2013), "correctional counseling is about helping persons who are troubled in one way or another or in most cases in trouble" (p.3). Officers that are able to develop working relationships with minors, are displaying dual roles. They are demonstrating public safety by enforcing rules and the regulations. In addition, they are being counselors by encouraging minors to conduct positive behavior. Officers can develop this relationship by listening to minors and demonstrating empathy (Kennealy et al 2012). Using the representative bureaucracy theory, I aim to demonstrate if officers' race and gender have an influence on officers pursuing the advocate role on behalf of minors.

\subsection{Representative Bureaucracy}

The representative bureaucracy theory suggests that minority bureaucrats or minority detention services officers will be inclined to support policies that serve minority clients. As Selden (1997) noted, "The presence of underrepresented groups should enhance the majority groups' empathic understanding and responsiveness to previously underrepresented or excluded groups" (6). According to this theory, representative bureaucracy might mitigate violent behavior via detention officer advocacy in juvenile halls.

Previous research from Selden (1997) points out, "the theory suggests that minority administrators, for example, will share attitudes and values with minorities in the general population and will therefore act to represent racial minority interests when opportunities to do so arise in the policy process" (5). Representative bureaucracy is a two-part concept that consists of passive and active representation:

Passive representation occurs when the representative resembles the represented on one or more dimensions (race, ethnicity, gender, etc.). Active representation occurs when the representative acts in the interests of the represented - that is, takes action that the representative thinks will benefit the represented. The theory of representative bureaucracy focuses on this translation of passive to active representation by addressing whether and when a bureaucrat makes decisions that benefit the persons 
being represented (Meier and O'Toole 2006, 71).

Passive representation in the probation department context is when an officer represents minors by sharing same race, ethnicity, and gender. Active representation in juvenile detention facilities is the behavior of the detention services officers; a decrease in violence is the expected result of this active representation. There is also symbolic representation, which is the presence of the bureaucrats race, ethnicity and gender influences the attitudes and behaviors of the represented client (Gade and Wilkins 2012). As noted by Gade and Wilkins (2012), "Symbolic representation argues that the presence of minority representatives, in and of itself, can change the behavior of the clients and their perceptions about the legitimacy of government" (p. 270). In their study, they examined the presence of Veteran services providers to determine if their clients are receiving quality service. Using surveys and interviews they were able to determine that the mere presence of service providers that are veterans influenced the level of clients' satisfaction with the program. In this study, I am unable to measure the minors' perception about detention services officers, however I am able to study the perceptions of officers as it pertains to passive representation and the potential for active representation.

The potential for active representation in this study occurs when the officer adopts an advocacy role toward minors and promotes attitudes toward preventing youth-on-youth violence. Pitts and Roch (2009) argue, "Passive representation is likely to 'translate' to active representation when bureaucrats are afforded discretion in their jobs through policymaking or implementation, when the policy issue is salient to the specific group being represented, and when professional norms appear unlikely to inhibit this transition" (p. 2). This article only focuses on race and gender as passive representation and preventing youth violence as the potential for active representation. The potential for active representation can occur when minority detention services officers have better communication and shared values with minority minors. In Lim's (2006) study he discusses how scholars agree on the passive representation of representative bureaucracy, yet there are variations if active representation does occur. Active representation is the behavior of detention services officers, whereas the decrease in violence is the expected result from this active representation. Therefore, this study can only observe the attitudes of officers that are likely to advocate for minors.

Criminal justice is a field where there is a lack of representative bureaucracy studies. In Bradbury and Kellough's study (2011) they discuss various criminal justice research that supports active representation. For example, they found in Close and Mason's study $(2006,2007)$ that police officers that shared the same race to the drivers during traffic stops where less likely to search their vehicle. However, white officers were more likely to search African American drivers. In a separate study, Brown and Frank (2006) found that White officers are more likely to make arrests than their Black colleagues. However, Black officers were more likely to arrest a Black suspect.

In terms of representative bureaucracy pertaining to gender in the criminal justice field. Meier and Crotty (2006), found that female victims of sexual assault were more likely to report their incidences to female officers. They used a pooled time series analysis observing 60 major cities, which concluded the higher percentage of female officers were linked to more reports on sexual assault. The presence of female officers can encourage female victims to share information, which can help prevent violence (Meier and Crotty 2006). In addition, Miller and Segal (2014) were able to determine that as female officers increased in an area, domestic violence was more likely to be reported.

In the corrections field, Vidal et al (2013) was able to determine that female youth offenders experience low recidivism when they have interpersonal relationships with their parole officers (PO). According to Vidal et al. (2013). "POs have the capacity to develop and establish meaningful relationships with their clients" (p. 2). Crouch and Alpert (1982) suggest female correctional officers are also less punitive and more supportive toward inmates. Women officers are more likely to prevent violence and induce a calming effect on inmates than male officers. Worden (1993) suggests that the fact that women are socialized to be nurturing works along with gender to help reduce violence. For instance, female officers are able to rely more on their communication skills with inmates to mollify violent situations. Women officers are more likely to perceive themselves as peacekeepers than male officers (Leger 2007). As Rabe-Hemp and Schuck (2007) note, "As a consequence, women officers may be more likely to defuse or de-escalate police-citizen encounters, successfully resolving situations that might otherwise have led to violence" (p. 413). Female officers are more likely to be effective in providing comfort to victims. Homant and Kennedy (1983) suggest female officers provide more concern and are more likely to share information that is beneficial to woman inmates. In addition, Leger (2007) found public perceptions deem female officers to be helpful in containing violence and are sympathetic toward victims of crime. 
However, female officers may be perceived as weak by youth because of their gender. Pogrebin and Poole (1997) suggests that women are physically weaker than men and may not be able to help stop a confrontation among violent youth. Minors may perceive the job as only male-dominated requiring the qualities of authoritativeness, which female officers may lack. Therefore, minors may choose to protect themselves by engaging in youth violence. However, race is considered to be an influential factor especially for individuals working within detention facilities.

Detention services officers can pursue policies that can reduce youth violence such as interacting and developing a rapport with minors. This relationship between officers and minors could help reduce youth violence. According to representative bureaucracy if detention services officers mirror the population served in regards to race, ethnicity, and gender they will advocate and be supportive toward minority youth. As Bradbury and Kellough (2007) note, "this connection occurs according to the theory, because the demographic and social backgrounds of individual bureaucrats influence their socialization experiences and the development of attitudes, values, and opinions that ultimately affect their decisions on policy issues" (p. 698).

The majority of the populations in juvenile halls are minors of color. Minors within the juvenile facilities can be more apt to interact with officers who share the same race and gender. Minors may perceive that officers obtaining the same characteristics have encountered similar experiences and share common values (Pitkin 1967). As Selden (1997) notes, "The symbolic role results from the personal characteristics of distinctive group members, and the assumption that because of these characteristics, the bureaucracy has had experiences in common with other members of that group" (6). The presence of minority officers who share the same gender as minors could allow inmates to easily approach officers with their problems. Minors can be more willing to bond with them because of shared demographics regardless of whether officers identify themselves as passive representatives for minors.

Officers who represent minors "stand for" them and develop a working relationship with them. Pitkin (1967) notes, "Rather it depends on the representative's characteristics, on what he is or is like, on being something rather than doing something" (p. 61). Representation must require action. This connection is based on officers' beliefs and attitudes toward minors, which can influence their policy decisions within juvenile halls. The perceptions that youth have of officers is critical since minors can choose to confide in them because of their ability to use discretion. Also, if minors feel that officers are looking out for their safety, they will be more likely to develop working relationships with them. As Lipsky (1980) has stated, "Street-level discretion promotes workers' self-regard and encourages clients to believe that workers hold the key to their well-being" (p. 15). Minors who feel they can identify with officers can create better relationships.

We can gain additional insights into representative bureaucracy through studies of representation in other contexts. Hindera (1993) suggest that racial minority bureaucrats' decision making is related to policy outcomes for same race clients as the passive representation of Black administrators was found in the decisions and policies implemented for investigating discrimination claims against Black clients. An analysis on representative bureaucracy Pitts (2005) found a similar relationship such that same race teacher-student resulted in higher standardized test scores. Meier et al. (1993) also suggest that the presence of racial minority teachers will enhance racial minority students' performance. They confirm linkage between representative bureaucracy and performance because minorities will implement policies that are favorable to minority clients. For instance, minority teachers are able to influence students' performance because they can serve as role models and are more inclined to understand the culture of minority students. Further studies have found that Hispanic police officers are more likely to be concerned with the welfare of Hispanic suspects than non-Hispanic officers (Selden 1997). Administrators determine whether their race or ethnicity influences their decision-making on policies based on the role perception they obtain for themselves. If bureaucrats perceive themselves as a minority advocates, they will be more likely to use their role to benefit minority clients. When bureaucrats do not perceive themselves as advocates, they will more likely to take on a neutral role where policy decisions do not benefit minorities (Pitts 2009).

Selden, Brudney, and Kellough (1998) suggest that public administrators who are similar in race and ethnicity will represent the minority public favorably and will lead to policy outcomes that represent the interests of clients. They state, "As a consequence, a number of scholars have endorsed the view that bureaucratic power to mold public policy can be made more responsive to public interests if the personnel in the bureaucracy reflect, in characteristics such as race, ethnicity, and gender, the public served" (718). Selden et al. (1998) conclude that administrators in the federal government do undertake a minority representative role, which implements policies favored to minorities. For instance, as bureaucrats' districts obtained a higher ratio of Blacks, Hispanics, and Asians bureaucrats, these individuals were more likely to grant loans to clients who shared the same race. They 
were more likely to grant loans to minorities than White bureaucrats. Selden et al. (1998) note, "Some administrators, especially minorities, may feel an intense sense of responsibility to minority communities" (721).

Race has a strong impact on bureaucrats' perception of their role (Ibid 1998). Minority employees are assumed to automatically undertake this advocate role, yet they also find non-minority administrators pursue the advocate role and policies favorable to minorities based on their social upbringings and by being culturally sensitive to minority issues. Selden (1997) points out that, "Administrators who perceive their role as that of an advocate or representative of minority interests are more likely to make decisions that benefit the minority community" (123). Selden finds the representative role rather than race has an influence on minority interests in active representation (Selden 1997). Selden's research is limited to examining bureaucrats and the policies they support that favor clients who share the same race in a federal government setting. This study is interested in understanding what factors lead bureaucrats in perceiving they have different roles; whether they perceive themselves to be advocates or traditional officers.

Bradbury and Kellough (2007) adapted the minority representative role as suggested by Selden (1997) in a local government setting by focusing on the attitudes of public administrators and Black clients. Bradbury and Kellough's (2007) study builds on the framework of representative bureaucracy by examining the passive-to-potential active link in the minority representative role. They found that attitudes between Black administrators and Black clients were the same, yet White administrators and Black clients held different attitudes. As indicated by Meier (1993), "The theory of representative bureaucracy concerns the ability of bureaucrats to translate values linked to demographic origins into decisions that benefit individuals or similar origins" (p. 1).

\section{Research Methods}

This study expands on observing the passive-to-potential active link of detention service officers' attitudes of their role and perceptions toward minors. This study interviews two groups, which are retired detention officers and volunteers that worked within the Los Angeles County Juvenile Halls and residential camps. Volunteers were chosen since they have close interactions with minors and detention services officers. They are able to observe the interactions among Detention Services Officers and minors. Detention services officers escort minors to religious services and after the mass they are entitled to one hour of bible study with the volunteers within the juvenile unit (Kita 2015). Retired detention officers were easier to interview since they made the time to participate in the study. I attempted to interview current detention services officers, but was unable to get someone to participate due to time constraints.

This study takes the exploratory approach by using representative bureaucracy as the foundation to understand if interviewees perceive minority officers pursuing the advocate role for minority minors. Same gender of detention officers to minors is also addressed to determine if officers that share the same gender to minors pursue the advocate role. The purpose of the exploratory study is to expand on the theory of representative bureaucracy in a juvenile justice setting.

Qualitative research was best suited for this study to understand the perspectives of these individuals (Strauss and Corbin 1998). Interviews were conducted using a snowball sample by contacting the office of Restorative Justice within the Los Angeles Catholic Diocese. The office of restorative justice advocates for positive changes in the criminal justice system and is dedicated to helping youth have a second chance for rehabilitation (ADLA 2015). The Catholic religion is a strong advocate in terms of forgiveness and advocates its followers to turn to prayer in times of need. The Catholic Church promotes peace. As stated by O'Brien (2013), "It seeks to prevent, engage, reduce, transform and help communities move beyond violence in all forms, including structural" (p.1) Therefore, the Catholic Church is deeply concerned with rehabilitation of minors during and after incarceration. Religious volunteers that interacted with minors were contacted for the interviews. Volunteers recommended other volunteers to participate in the study as well as retired detention officers. Los Angeles County detention facilities are of interest to this study since the majority of juvenile halls and juvenile camps are located in Southern California (LAO 1995). In addition, the Los Angeles County Probation Department is one of the largest departments in the world (LA Probation Dept. 2015).

Interviews were conducted over the telephone in fall 2011 focusing on individuals that had worked or volunteered within Los Angeles County Juvenile Halls, Camps and Youth Correctional Facilities. Interview questions were semi-structured which allows the interviewee to expand on concepts and themes. Some of the benefits in using telephone interviews was the ability to engage in relaxed conversations with interviewees. The interviewees were able to talk freely, which allowed for increase rapport about the subject (Novick 2011). There were a total of 10 interviewees that were both female $(\mathrm{N}=5)$ and male $(\mathrm{N}=5)$ whose ages ranged from 30 to 65 
years old.

Research on youth violence is scarce, and the few reports that do exist only list the causes of violence but do not give the perspectives of individuals who have actually worked with at-risk youth. The aim of this study is to understand how these individuals perceive officers and what they perceive to be the causes to violence. The grounded theory approach was used for data analysis by observing common responses among participants. Open coding was used for the analysis to group similar themes that were repetitive. The information was categorized into four different themes. The four category headings generated from the data were: 1) causes of youth violence, 2) perceptions on officers, 3) do gender and ethnicity improves relationships? and 4) how to reduce youth violence. In addition, excerpts from the interviews are included in these sections that are designed to represent key themes that emerged.

\subsection{Causes of Youth Violence}

Each of the interviewees was asked, "What do you believe are the three main causes for youth-on-youth violence?" This question was asked because there can be various reasons why youth violence occurs. This helped to identify various factors that can influence violence and to find out which responses were common among the participants. The three common themes were 1) bullying, 2) gang-related, and 3) inferiority. The following three excerpts are representative of comments made by the interviewees:

Minors put a lot of demand on others so that they won't be picked on. It's the bullying effect.

Yes, there are gang issues. There are also causes in the institutions for the most part what happens with gangs. What we usually have is when a kid comes into the institution with a rival gang member. What usually happens they fight then squash it, or they become friends and they get along.

Youth resort to violence or violent type situations when there is a lot of anger and low family involvement. And low socioeconomic status. The economics of the home.

When there is a lot of worry over money. This brings about issues at the house. The parents are always trying to make ends meet. They are often times not loving; there is a lot of anxiety, anger that trickles down to the youth.

For each theme, the results were 1) bullying $(n=5), 2)$ gang-related $(n=6)$, and 3$)$ inferiority $(n=4)$ for all groups. Few individuals indicated that violence was the result of racial tension $(\mathrm{n}=3)$. According to one interviewee, "This only happens when it gets labeled that way from staff." The interviewee suggested by his tone and statement that staff play a role in racial tension and can escalate the situation if they keep discussing the race card.

In addition, other interviewees suggested that at-risk youth are exposed to many dangers due to their socioeconomic environment $(\mathrm{n}=2)$. As one interviewee noted, "They become victims first, then they become the victimizers." This suggests that a lack of education and counseling exists for these youth to deal with their personal problems, leading them to hurt other people or things. Overall the findings depict that minors cause violence due to personal problems related to how they were treated while growing up. Racial fighting, especially among the Black and Hispanic communities, has gained attention in news reports, but racial fighting was not depicted as one of the main causes of violence.

\subsection{Perceptions on Officers}

Interviewees were also asked if they perceive that officers can be advocates for youth: "Do you feel that it is easy for officers to advocate for minors?" The majority of the respondents felt that officers could be advocates for youth $(\mathrm{n}=6)$. The following three excerpts represent this perception of officers.

Yeah, from what I can tell. In talking to kids over the years, they constantly refer to their Probation Officers (P.O.). Kid says, "Well my P.O. thinks if I don't screw up, I'll get an early release." They do talk about their Probation Officers in positive terms.

I think that it's a very challenging job. I know very good counselors that take really good pride. Because they believe they can be a positive influence in the kids'lives. The relationship is one of mutual respect, believing in the young people's potential.

Yes, they have access to them. They have access to the youth at the center. Is it a doable thing. Yes, I think so.

A few interviewees disagreed that officers have an easy task of being an advocate. Four respondents suggested that officers are unable to be advocates because they often stereotyped youth. One interviewee stated, "Their 
chances to succeed are very low. By the time the kid hits juvenile hall they have broken many laws." In addition, another interviewee noted, "They didn't see the goodness of the kid, but they see the bad side because of them working in the juvenile system. They stereotyped children by their race, neighborhood, and if they were gang members." These two statements reflect two different people: a former officer and a volunteer who worked within the juvenile system. However, both statements relate to the concept that officers were more likely to label youth as being bad and not being able to turn them into being good citizens even if officers did display the advocate role. This disparity needs to be explored further to determine if officers can improve their perception of being advocates.

\subsection{Do Gender and Ethnicity Improve Relationships?}

Interviewees were asked if officers' race and gender can help minors' behavior. All interviewees were asked, "Do you feel that officers that share similar characteristics such as race and gender to minors can help improve minors' behavior and reduce violence?" The majority of the respondents $(n=7)$ did feel that officers who shared the same race and gender as minors did help improve minors' behavior. The following are a few excerpts:

Youth of color are more immediately drawn to people who look like them and who they perceive to have had similar life experiences.

Most definitely! I witnessed it in the halls, race and language they will be able to gravitate to them more. The kids look up to them.

I think that it does. I think having the cultural awareness and cultural similarities. I think they are able to relate better to youth. Because of similar circumstances they were able to understand where the kids were coming from and kind of have some interaction with. For instance, for other officers it would take a little longer for them to establish the relationship.

Also, a good African officer that can work with Latino youth can break the Black and Brown stigma. I think there is danger if the staff is not doing what he or she is supposed to do. That can have a potential of creating a lot of problems showing favoritism.

Officers who share similar characteristics may have an easier time at building relationships with youth who are also of the same race and gender. However, two respondents $(n=2)$ suggested that staff of any race can connect with youth as long as they show interest in them.

Interviewees also elaborated on the importance of matched gender. The following are a few excerpts as it relates to females:

Many young women who are in custody have been sexually abused or used by men or older boys. They really don't want anything to do with males. They very much gravitate toward women staff who get that. They are young, but they are world-wise survivors. They respond to female staff who are genuine and who recognize what they have been through and listen to them.

In my experience the women staff can either be young or old - the young ones who can relate to having "been there" can serve as role models, but I have also seen boys and girls gravitate to older women staff who play more of an auntie or grandma type supportive role.

A few officers also suggested the importance of having a positive male role model. As one interviewee stated, "Having good men staff can also be great, especially for detained boys. So many of detained youth have grown up without a strong, positive male role model in their lives outside." Another interviewee noted, "I also believe it's important for young men to have older male mentors that can guide them and speak to them in ways they identify them as a male role model." Young males grow up without an appropriate father figure in the household, which they seek in the streets. Officers have the opportunity to connect with youth in these facilities, and officers who share similar characteristics with youth can be helpful in creating these relationships. Staff members can be role models to youth, which can help improve their outlook on life.

\subsection{How to Reduce Youth Violence?}

Interviewees were asked, "What do you feel is the best method to reduce youth violence?" This question was asked because it helps to understand the participants' point of view and provides input on what they feel can reduce violence. Their perception is important since they have experience working with the at-risk youth population. They may have also tried implementing some of these activities for youth or have observed youth in their environment implementing one of these activities. The majority of the respondents $(n=6)$ suggested that education is important for youth to attain especially inside the detention centers. The following are a few excerpts: 
To educate them and let them know they have a reason to live.

Youth who have something to look forward to, and who have the means to get there in terms of having a good education.

If we can provide a good education, maybe they'll go back to school.

The remaining respondents suggested different ways of reducing violence. The following outcomes were the ones mentioned (number of interviewees in parentheses):

- Community programs suggested by youth (1)

- One-on-one therapy, group, family counseling, mentoring programs (1)

- Exercise programs (1)

- $\quad$ Events planned by youth (1)

Juvenile facilities programs that are catered to youth and their development, such as in physical, mental, and social fulfillment, can help reduce youth violence. Some of these programs do exist in the facilities, such as exercise programs and counseling, but they need to be consistent. In addition, youth should also have the opportunity to suggest new programs or new events to staff members. This can help motivate youth to improve their behavior. For instance, a personal conversation with an officer in 2005 suggested that minors would suggest their own version of American Idol such as teen idol or rap idol where minors compete with each other through music. The winner would win an additional 10 minutes for a personal phone call or a snack. Staff members can also create some type of incentive structure for minors to display good behavior. This is the discretion they have as being officers in detention youth facilities.

\section{Results of the Study}

The results of this analysis indicate that detention officers are more likely to pursue the advocate role for minors, especially when officers share the same race and gender to minors. Officers that are the same race and gender to minors can be more likely to develop working relationships with youth. However, it is important to point out that some interviewees $(n=4)$ felt that detention officers were unable to pursue the advocate role due to officers stereotyping the minors. The problem of negatively labeling youth based on race can play a factor on officers' perceptions on dealing with youth. For example, if an officer has a negative perception on youth they may not be readily willing to correct the minors' behavior (Misis et al 2013). If an officer, has a positive perception of minors they may be more willing to help them, which can lead to decreasing youth violence.

The interviewees were also asked what they perceive to be the main causes of violence. Bullying and gang tension were the key indicators of violence in juvenile detention facilities. Bullying is in-depth subject, which is usually researched in educational fields. Bullying can be verbal, physical, threatening or using violence. Individuals use bullying to prove they are stronger and have power over another person (Seeley et al 2011). In order for minors to protect themselves from bullying, they rely on gangs for protection, support and for a sense of belonging (Forber-Pratt et al 2014). If a minor has entered a juvenile facility with no gang affiliation, they may be more pressured to join one within the institution for protection. Most minors incarcerated have already joined a gang in their social environments' prior to their stay in detention facilities, which leads to gang violence.

In order to reduce youth violence in detention facilities interviews suggested education is important for minors to learn and aspire to better themselves. According to one interviewee, he indicated that some minors were illiterate and needed help on reading. Therefore, he took it upon himself to create a reading club to help the minors read. Learning can be the tool to help minors succeed and can possible motivate them to achieve a positive future. Another way to reduce youth violence is to help minors suggest or plan extracurricular activities. These can be workshops that are of interest to youth that are administered by the detention officers. These types of activities can help cultivate a working relationship with youth and help deter violence.

\section{Limitations}

There are limitations to this study, and the limitations are presented as follow:

1) This study is not generalizable to other juvenile detention centers. The county of Los Angeles was used for this study since it is considered to be one of the largest probation departments that facilitate juvenile halls, camps and correctional facilities in the nation and in the world (LA Probation Dept. 2015). The demographic of Los Angeles County may not comparable to other settings across the U.S. especially when it comes to officers sharing the same race and gender to minors. Urban areas may have high level of minorities incarcerated than non-urban areas, which could lessen the likelihood of officers pursuing the advocate role. 
2) Phone interviews can also be a limitation to the study. During a phone interview I am unable to see the interviewee nor pick up on non-verbal cues such as body language. This lack of physical interaction may limit the ability to establish additional information that can be helpful to the study.

3) The sample size of 10 interviews is also a limitation and the use of the snowball sample was only able to provide volunteers and retired officers due to time constraints.

\section{Recommendations for Future Research}

Since this study was only able to interview volunteers and retired officers, future research is to interview current officers that are working within juvenile facilities. Interviewing officers that are currently working within juvenile facilities can provide useful information on their perspectives if sharing similar characteristics to minors helps them develop easier relationships with youth. Based on the findings, recommendations for future research is to extend the research study to include major urban cities across the United States. The Los Angeles Probation Department was used for this study since it is one of the largest Probation departments in the world. Future research to include other major cities in the United States in comparison to Los Angeles can provide interesting results. In addition, comparing non-urban cities such as institutions situated in rural areas can help determine if representative bureaucracy can be upheld due to the demographics of officers and minors. Future research can also include interviewing the minors to determine their perceptions of officers and if they feel more comfortable with officers that share similar characteristics.

\section{Conclusions}

Based on the findings of this study a policy implication is for juvenile correctional institutions to hire minority officers or to hire officers that mirror the youth population incarcerated. Working units should have a diverse set of officers based on their ethnicity and gender working with the youth. This can help minors understand how people of different color work together. In addition, juvenile institutions should provide training regardless of race and gender to the officers on becoming role models for youth. The majority of youth do not have positive role models by the time they enter a juvenile correctional facility. Therefore, if officers are able to display genuine respect for youth, minors may have a second chance at living a better life.

According to this study's finding, minors' gravitate toward officers that share similar characteristics, therefore these minors may share personal information to officers such as their family upbringing and personal goals. Minors may look up to officers more as counselors, which can help in their rehabilitation. Correctional officers have a challenging position by displaying dual roles of portraying public safety to ensure security and counseling. Administration in juvenile facilities can provide appropriate training support to help correctional officers meet the needs of their position and help minors achieve the necessary care within juvenile institutions.

In conclusion, this study provides an exploratory approach to understanding how representative bureaucracy can have an impact on minority detention officers pursuing the advocate role for minority minors. The passive to potential active link in representative bureaucracy was used as guide to understand if the relationship between detention officers and minors upholds within the juvenile justice arena. This study was able to determine that race and gender did have an influence on officers pursuing the advocate role for minority minors. In addition, this study was able to identify themes associated with youth violence in juvenile detention facilities such as bullying and gang tension. As well as to understanding ways to remedy youth violence in juvenile facilities.

\section{References}

Archdiocese of Los Angeles. (2015, June 21). Restorative Justice. Retrieved from http://www.la-archdiocese.org/org/orj/Pages/default.aspx

Balint, E. (2015, July 19). Assaults, fights common in youth prison system. Indie Online Retrieved from http://indieonline.com

Bradbury, M. D., \& Kellough, J. E. (2007). Representative bureaucracy: Exploring the Potential for Active Representation in Local Government. Journal of Public Administration Research, 18, 697-714. http://dx.doi.org/10.1093/jopart/mum033

Bradbury, M. D., \& Kellough, J. E. (2011). Representative Bureaucracy: Assessing the Evidence on Active Representation. The American Review of Public Administration, 41(2), 157-161. http://dx.doi.org/10.1177/0275074010367823

Brown, R. A., \& Frank, J. (2006). Race and officer decision making: Examining differences in arrest outcomes between black and white officers. Justice Quarterly, 23, 96-126. http://dx.doi.org/10.1080/07418820600552527 
Close, B. R., \& Mason, P. L. (2006). After the traffic stops: Officer characteristics and enforcement actions. Topics in Economic Analysis \& Policy, 6, 1-41. http://dx.doi.org/10.2202/1538-0653.1538

Close, B. R., \& Mason, P. L. (2007). Searching for efficient enforcement: Officer characteristics and racially biased policing. Retrieved from http://www.bepress.com/rle/vol3/iss2/art5

Cohen-Jennings, V. (2010). The Overrepresentation of Young Black Males within Correctional Institutions. Florida Department of Law Enforcement.

Crouch, B. M., \& Alpert, G. P. (1982). Sex and Occupational Socialization among Prison Guards: A Longitudinal Study. Criminal Justice and Behavior, 9(2), 159-176. http://dx.doi.org/10.1177/0093854882009002004

Dance, S. (2012, April 14). Youth Violence, Staff Force spiked in 2011 at troubled juvenile Detention Facilities. The Baltimore Sun. Retrieved from http://baltimoresun.com

Forber-Pratt, A. J., Aragon, S. R., \& Espelage, D. L. (2013). The Influence o-f Gang Presence on in One Middle School Environment. Psychology of Violence, 4(1), 8-20. http://dx.doi.org/10.1037/a0031835

Gade, D. M., \& Wilkins, V. M. (2012). Where Did You Serve? Veteran Identity, Representative Bureaucracy, and Vocational Rehabilitation. Journal of Public Administration Research and Theory, 23, 267-288. http://dx.doi.org/10.1093/jopart/mus030

Grissom, B. (2012, February 12). Agency Will Investigate Violence in Texas Youth Prisons. The Texas Prison. Retrieved from http://texastribune.org

Hawkins, J. D., Herrenkohl, T. I., Farrington, D. P., Brewer, D., Catalano, R. F., Harachi, T. W., \& Cothern, L. (2000). Predictors of Youth Violence. Juvenile Justice Bulletin, Office of Juvenile Justice and Delinquency Prevention: 1-11. http://dx.doi.org/10.1037/e524202006-001

Hindera, J. J. (1993). Representative Bureaucracy: Further Evidence of Active Representation in EEOC District Offices. Journal of Public Administration and Review, 3, 415-429.

Holman, B., \& Ziedenberg, J. (2006). The Dangers of Detention: The Impact of Incarcerating Youth in Detention and Other Secure Facilities. Juvenile Policy Institute Report.

Homant, R. J., \& Kennedy, D. B. (1983). Attitudes of Abused Women toward Male and Female Police Officers. Criminal Justice and Behavior, 10(4), 391-405. http://dx.doi.org/10.1177/0093854883010004002

Jacobs, J. B., \& Lawrence J. K. (1978). Integrating the Keepers: A Comparison of Black and White Prison Guards in Illinois. Social Problems, 25(3), 304-318. http://dx.doi.org/10.2307/800067

Jurik, N. C. (1985). Individual and Organizational Determinants of Correctional Officer Attitudes Toward Inmates. Criminology, 23, 523-539. http://dx.doi.org/10.1111/j.1745-9125.1985.tb00352.x

Kennealy, P. J., Skeem, J. L., Manchak, S. M., \& Louden, J. E. (2012). Firm, fair, and caring officer-offender relationships protect against supervision failure. Law and human behavior, 36(6), 496-505. http://dx.doi.org/10.1037/h0093935

Kita, G. F. (2015). Los Angeles Criminal Defense Lawyer. Retrieved from http://www.topjuveniledefender.com/

Leger, K. (1997). Public perceptions of female police officers on patrol. American Journal of Criminal Justice, 21(2), 231-249. http://dx.doi.org/10.1007/BF02887451

Legislative Analyst Office. (1995, May). Juvenile Crime-Outlook for California Part V. Retrieved from http://www.lao.ca.gov/1995/050195_juv_crime/kkpart5.aspx

Levey, N. N. (2006, March 1). Violence Undermines County Juvenile Hall. The Los Angeles Time. Retrieved from http://latimes.com

Lim, H. H. (2006). Representative Bureaucracy: Rethinking Substantive Effects and Active Representation. Public Administration Review, 66(2), 193-204. http://dx.doi.org/10.1111/j.1540-6210.2006.00572.x

Lipsky, M. (1980). Street-Level Bureaucracy: Dilemmas of the Individual in Public Services. New York: Russell Sage.

Los Angeles County Probation Department. (2013). Detention Services Officer (DSO) Job Description. Retrieved from http://probation.lacounty.gov

Los Angeles County Probation Department. (2015). About Us. Retrieved from http://probation.lacounty.gov

Meier, K. J. (1993). Latinos and Representative Bureaucracy: Testing the Thompson and Henderson Hypotheses. Journal of Public Administration Theory, 3(4), 393-414. 
Meier, K. J., \& Crotty-Nicholson, J. (2006). Gender, Representative Bureaucracy, and Law Enforcement: The Case of Sexual Assault. Public Administration Review, 66(6), 850-860. http://dx.doi.org/10.1111/j.1540-6210.2006.00653.x

Meier, K. J., \& O’Toole Jr, L. J. (2006). Bureaucracy in a Democratic State: A Governance Perspective. Maryland: The John Hopkins University Press.

Mendel, R. (2011). No Place for Kids: The Case for Reducing Juvenile Incarceration. The Annie E. Casey Foundation. Baltimore, Maryland.

Miller, A. R., \& Segal, C. (2013). Do Female Officers Improve Law Enforcement Quality? Effects on Crime Reporting and Domestic Violence Escalation. Retrieved from http://ssrn.com/abstract=2335990

Misis, M., Cheeseman, K., Hogan, N. L., \& Lambert, E. G. (2013). The Impact of Correctional Officer Perceptions of Inmates on Job Stress. Sage Open, 3(2), 1-13. http://dx.doi.org/10.1177/2158244013489695

Novick, G. (2008). Is There a Bias Against Telephone Interviews In Qualitative Research? Research in Nursing and Health, (4), 391-398. http://dx.doi.org/10.1002/nur.20259

O'Brien, D. (2013, March). Catholic Strategic Peacebuilding: The Unique Role of the Laity. Retrieved from http://www.beyondintractability.org/reflection/obrien-catholic-strategic- peacebuilding

O’Brien, R. D. (2015, May 31). Violence Is Down but Still Rampant At Juvenile Detention Facilities. Wall Street Journal. Retrieved from http://wsj.com

Pace, F. (2015, July 27). Juvenile center in Julian no longer safety, advisory board. Williamson Daily News. Retrieved from http://williamsondailynews.com

Pitkin, H. F. (1967). The Concept of Representation. Berkeley: University of California Press.

Pitts, D. W. (2005). Diversity, Representation, and Performance: Evidence about Race Ethnicity in Public Organizations. Journal of Public Administration Review, 15, 615-631. http://dx.doi.org/10.1093/jopart/mui033

Pitts, D. W., \& Roch, C. (2009). Differing Effects of Representative Bureaucracy in Charter Schools and Traditional Public Schools. Unpublished Manuscript.

Pogrebin, M. R., \& Poole, E. D. (1997). The Sexualized Work Environment: A Look at Women Jail Officers. The Prison Journal, 77, 41-57. http://dx.doi.org/10.1177/0032855597077001004

Rape-Hemp, C., \& Schuck, A. M. (2007). Violence against police officers: Are Female Officers at Greater Risk? Police Quarterly, 10(4), 411-428. http://dx.doi.org/10.1177/1098611107304326

Seeley, K., Tombari, M. L., Bennett, L. J., \& Dunkle, J. B. (2011). Bullying In Schools: An Overview. U.S. Department of Justice.

Selden, S. C. (1997). The Promise of Representative Bureaucracy: Diversity and Responsiveness in a Government Agency. New York: M.E. Sharpe.

Sewell, A. (2015, April 15). Amid conflicting reports, L.A. County board orders audit of Probation agency. The Los Angeles Times. Retrieved from http://latimes.com

Thompson, F. J. (1976). Minority Groups in Public Bureaucracies: Are Passive and Active Representation Linked? Administration and Society, 8(2), 201-226. http://dx.doi.org/10.1177/009539977600800206

Van Voorhis, P. V., \& Salisbury, E. J. (2013). Correctional Counseling and Rehabilitation (8th ed.). Routledge.

Vidal, S., Oudekerk, B. A., Reppucci, N. D., \& Woolard, J. (2013). Examining the Link between Perceptions of Relationship Quality with Parole Officers and Recidivism Among Female Youth Parolees. Youth Violence and Juvenile Justice, 1-17.

Vivian, J. P., Grimes, J. N., \& Vasquez, S. (2007) Assaults in Juvenile Correctional Facilities: An Exploratory Study. Journal of Crime and Justice, 30(1), 17-34. http://dx.doi.org/10.1080/0735648X.2007.9721225

Worden, A. P. (1993). The Attitudes of Women and Men in Policing: Testing Conventional and Contemporary Wisdom. Criminology, 31, 203-241. http://dx.doi.org/10.1111/j.1745-9125.1993.tb01128.x

Wordes, M., Krisberg, B., \& Barry, G. (2001). Facing the Future Juvenile Detention in Alameda County. National Council on Crime and Delinquency, 1-13.

Zhang, S. (2007). Youth-on-Youth Violence in Los Angeles County Juvenile Detention Camp Facilities: A Comparative Analysis. San Diego, CA: San Diego State University. 


\section{Copyrights}

Copyright for this article is retained by the author(s), with first publication rights granted to the journal.

This is an open-access article distributed under the terms and conditions of the Creative Commons Attribution license (http://creativecommons.org/licenses/by/3.0/). 